\title{
Performance of Crop Residue Management Practices on Growth and Yield of Wheat (Triticum aestivum L.) under Rice- wheat System in Bastar Region of Chhattisgarh, India
}

\author{
Anil Kumar Netam ${ }^{1 *}$, Birbal Sahu ${ }^{2}$, Chainu Ram Netam ${ }^{3}$ and Suresh Kumar Markam² \\ ${ }^{1}$ AICRP on IFS - On Farm Research, IGKV, Krishi Vigyan Kendra, Kanker, \\ Chhattisgarh, India \\ ${ }^{2}$ Krishi Vigyan Kendra, Kanker, Chhattisgarh, India \\ ${ }^{3}$ College of Agriculture \& Research Station, Bemetara, Chhattisgarh, India \\ *Corresponding author
}

\begin{tabular}{|l|}
\hline Ke y w o r d s \\
Crop residue \\
management, \\
Wheat, Varieties, \\
Growth, Crop \\
stages, Yield, \\
Economics \\
\hline Article Info \\
\hline $\begin{array}{l}\text { Accepted: } \\
\text { 04 May } 2019 \\
\text { Available Online: } \\
\text { 10 June } 2019\end{array}$ \\
\hline
\end{tabular}

A B S T R A C T

A field experiment conducted during the Rabi season, 2016-17 at the Instructional Farm, Shaheed Gundadhoor College of Agriculture \& Research Station, Kumhrawand, Jagdalpur District- Bastar (Chhattisgarh). The soil of experimental site was sandy loam; it was low in organic carbon $(0.44 \%)$ and available nitrogen $\left(235.15 \mathrm{~kg} \mathrm{ha}^{-1}\right)$ and medium in available phosphorus $\left(13.10 \mathrm{~kg} \mathrm{ha}^{-1}\right)$ and potassium $\left(291.33 \mathrm{~kg} \mathrm{ha}^{-1}\right)$ and acidic in reaction $(6.2 \mathrm{pH})$. The experiment was laid out in spilt plot design with three crop residue management practices and four varieties of wheat. Three residue management practices viz. Residue burnt + tillage $\left(\mathrm{T}_{1}\right)$, Residue incorporation $\left(\mathrm{T}_{2}\right)$ and Residue retention $\left(\mathrm{T}_{3}\right)$, were applied in main plot and four varieties viz. GW- $273\left(\mathrm{~V}_{1}\right)$, Lok- $1\left(\mathrm{~V}_{2}\right)$, Kanchan $\left(\mathrm{V}_{3}\right)$ and Sujata $\left(\mathrm{V}_{4}\right)$ in sub-plot and replicated 3 times. The results revealed that treatment residue retention recorded relatively higher plant height $(16.90 \mathrm{~cm})$ at 15 DAS, whereas treatment residue incorporation recorded relatively higher plant height $(26.42 \mathrm{~cm})$ at 30 DAS, $(57.51 \mathrm{~cm})$ at 45 DAS and $(75.09 \mathrm{~cm})$ at $60 \mathrm{DAS},(93.28 \mathrm{~cm})$ at $75 \mathrm{DAS},(96.74 \mathrm{~cm})$ at $90 \mathrm{DAS}$ and $(97.28 \mathrm{~cm})$ at harvest. The varieties GW-273 recorded significantly higher plant height $(17.66 \mathrm{~cm})$ at $15 \mathrm{DAS}$ and $(26.81 \mathrm{~cm})$ at 30 DAS, variety LOk-1 recorded significantly higher plant height $(62.77 \mathrm{~cm}$ and $78.24 \mathrm{~cm})$ at $(45$ and 60 DAS) respectively. Significantly higher plant height recorded of variety Sujata (113.04 $\mathrm{cm})$ at 75 DAS, $(113.51 \mathrm{~cm})$ at 90 DAS and $(114.06 \mathrm{~cm})$ at harvest. Treatment residue retention recorded relatively higher number of tillers (427.92) at 15 DAS, whereas treatment residue incorporation recorded relatively higher number of tillers (693.75) at $30 \mathrm{DAS},(862.50)$ at 45 DAS, (618.75) at 60 DAS, (549.08) at 75 DAS, (545.67) at 90 DAS and (544.92) at harvest. The varieties Sujata recorded significantly higher number of tillers (749.44), (901.11) and (652.22) at 30, 45 and 60 DAS respectively, whereas variety Lok-1 recorded significantly higher number of tillers (577.22), (577.00) and (576.44) at 75 DAS, 90 DAS and at harvest respectively. The days to occurrence of crop growth stages more influenced due to varieties and less influenced due to crop residue management practices. Treatment residue incorporation recorded relatively higher grain yield $\left(40.63 \mathrm{q} \mathrm{ha}^{-1}\right)$, straw yield $\left(32.92 \mathrm{q} \mathrm{ha}^{-1}\right)$ and gross return (Rs. ha ${ }^{-1} 64,541$ ), whereas treatment residue retention recorded highest net return. (Rs. ha ${ }^{-1}$ 39,308) and B: C ratio (Rs. 2.81). Varieties Lok-1 recorded significantly higher grain yield $\left(43.36 \mathrm{q} \mathrm{ha}^{-1}\right.$ ), harvest index $(61.35 \%)$, gross return (Rs. ha $\left.{ }^{-1} 66,130\right)$, net return (Rs. ha ${ }^{-1}$ 41,452) and B: C ratio (Rs. 2.68). Variety Sujata produces significantly higher straw yield (34.83 q ha ${ }^{-1}$ ). 


\section{Introduction}

Rice (Oryza sativa L.) - Wheat (Triticum aestivum L.) cropping system is a the most predominant production and nutrient exhaustive system occupying about $18 \mathrm{M}$ ha in Asia, of which $13.5 \mathrm{M}$ ha area in IndoGangetic Plains of India, Pakistan (2.2 M ha), Bangladesh (0.8 M ha) and Nepal (0.5 M ha) and feeds about 1.3 billion people (20\% of the world population) (Farooq et al., 2007, Saharawat et al., 2010). Wheat occupies an area of 0.18 million hectares with the production of 0.28 million tones and average productivity of $1550 \mathrm{~kg} \mathrm{ha}^{-1}$ during 2017-18 (Anonymous, 2018) in the state and most of the area under rice- wheat system. Farmers normally use wheat straw as animal feed but rice straw is either burnt or used as animal feed and fuel source in rural area or incorporation in the field. Residue retention/incorporation into soil is an essential management practice to handle crop residue. The retention/incorporation of rice residues may affect soil fertility, soil physico chemical properties and yield of the crop.

Nutrients in crop residues and soil amendments are more available to crops if they are retained/incorporated into the soil rather than burnt, burning of crop residue destroys our precious natural resource (the organic matter) that may adversely affect soil physical, chemical and biological properties (Gangwar et al., 2006). The imbalance use of chemical fertilizers in the last four to five decades has led to the paralleled corresponding decline in the use of cover crops and organic manures. Conventional management practices have led in the decline in soil organic matter, increased soil erosion, and surface and ground water contamination. Until recently, we fail to recognize the consequences of management on the balance and cycling of energy and dry matter and soil productivity. Crop residues are tremendous natural resources not a waste. Residue management is receiving a great deal of attention because of its diverse effects on soil physical, chemical and biological properties (Kumar and Goh, 1999).

Information on the kinetics of decomposition of the crop residues and mineralization, immobilization turnover of different quality crop residues is required to ascertain the actual amount of crop residues needed to maintain the soil productivity and ensure environment protection by minimizing nutrient losses and soil erosion. Addition of soil organic matter to the soil through the return of crop residues, also improve soil structure, influences soil water, air and temperature relations, help control runoff and erosion and makes tillage easier. Crop residue is a good source of plant nutrients and important component for the stability of the agricultural ecosystem. About $25 \%$ of $\mathrm{N}$ and $\mathrm{P}, 50 \% \mathrm{~S}$ and $75 \%$ of $\mathrm{K}$ uptake by cereal crops are retained in crop residue, making them viable nutrient sources (Dotaniya, 2013). Crop residue and their proper management affect the soil quality either directly or indirectly. Intensive cropping system is very diverse and complex, so no one residue management system is superior under all situations. Ideally crop residue management practices should be selected to enhance crop yields with a minimum adverse effect on environment. It is suggested that in each cropping system the constraints to production and sustainability should identified and conceptualized to guide towards the best option. There is a need to identify and recommend a more productive, profitable and environmentally sound crop residue management system. Objective of this study was to examine the effects of the three crop residue management practices on growth and yield of wheat under rice- wheat cropping system. 


\section{Materials and Methods}

A field experiment was conducted during the Rabi season of 2016-17, at the Instructional Farm, Shaheed Gundadhoor College of Agriculture \& Research Station, Kumhrawand, Jagdalpur District- Bastar (Chhattisgarh). The soil of experimental site was sandy loam; it was low in organic carbon $(0.44 \%)$ and available nitrogen $(235.15 \mathrm{~kg} \mathrm{ha}$ ${ }^{1}$ ) and medium in available phosphorus (13.10 $\left.\mathrm{kg} \mathrm{ha}^{-1}\right)$ and potassium $\left(291.33 \mathrm{~kg} \mathrm{ha}^{-1}\right)$ and acidic in reaction $(6.2 \mathrm{pH})$. The experiment was laid out in spilt plot design with three crop residue management practices and four varieties of wheat. Three residue management practices viz. Residue burnt + tillage $\left(\mathrm{T}_{1}\right)$, Residue incorporation $\left(\mathrm{T}_{2}\right)$ and Residue retention $\left(\mathrm{T}_{3}\right)$, were applied in main plot and four varieties viz. GW- $273\left(\mathrm{~V}_{1}\right)$, Lok- $1\left(\mathrm{~V}_{2}\right)$, Kanchan $\left(\mathrm{V}_{3}\right)$ and Sujata $\left(\mathrm{V}_{4}\right)$ in sub-plot and replicated 3 times. Recommended dose of nutrients was 100:60:40 kg N: P: $\mathrm{K} \mathrm{ha}^{-1}$. Entire quantity of phosphorus \& potassium was applied before sowing. Nitrogen applied in three splits i.e. 50\% as a basal, 25\% at tillering and $25 \%$ at panicle emergence stage. Experiment was conducted under irrigated condition and irrigated 5 times in different crop stages. Crop seed sown on $30^{\text {th }}$ November, 2016 with a row spacing of $20 \mathrm{~cm}$. Herbicide pendimethalin 30 EC applied @ $0.75 \mathrm{~kg}$ ha- 1 in $3^{\text {rd }}$ day. The average maximum and minimum temperature varied between $27.8^{0} \mathrm{c}-33.7^{\circ} \mathrm{c}$ and $15.2^{\circ} \mathrm{c}-26.0^{\circ} \mathrm{c}$ respectively.

The plant height was measured randomly of 5 plants of each plot in centimeter from ground surface up to the tip of awn. The number of tillers counted from $0.25 \mathrm{~m}^{2}$ area by placing a quadrate of $0.5 \mathrm{~m} \times 0.5 \mathrm{~m}$ randomly at 4 places in each plot and then number of tillers $\mathrm{m}^{-2}$ worked out. Occurrence of crop stages recorded by visited every day at experimental site. The harvest index was calculated by dividing the grain yield with biological yield (grain + straw yield) and multiplied by 100 .

Harvest Index $(\%)=\frac{\text { Grain } \quad \text { yield }(\mathrm{q} / \mathrm{ha})}{\text { Biological } \quad \text { yield }(\mathrm{q} / \mathrm{ha})}$ X100

\section{Results and Discussion}

\section{Plant height}

Average plant height increased progressively with increase in the age of the crop. The plant gained height at relatively slower rate between 75 to 90 DAS and accelerated between 15 to 75 DAS. The Plant height of wheat varieties influenced significantly, whereas plant height of wheat did not influenced due to crop residue management practices (Table 1). Among the residue management practices treatment residue retention recorded relatively higher plant height $(16.90 \mathrm{~cm})$ at $15 \mathrm{DAS}$, while treatment residue incorporation recorded relatively higher plant height $(26.42 \mathrm{~cm})$ at 30 DAS, $(57.51 \mathrm{~cm})$ at $45 \mathrm{DAS},(75.09 \mathrm{~cm})$ at 60 DAS, $(93.28 \mathrm{~cm})$ at 75 DAS, $(96.74 \mathrm{~cm})$ at 90 DAS and $(97.28 \mathrm{~cm})$ at harvest, followed by treatment residue burnt along with tillage $(93.01 \mathrm{~cm})$ at 75 DAS, $(94.02 \mathrm{~cm})$ at 90 DAS and $(94.81 \mathrm{~cm})$ at harvest.

Among the varieties GW-273 recorded significantly higher plant height $(17.66 \mathrm{~cm})$ followed by Sujata $(16.28 \mathrm{~cm})$ at 15 DAS. Variety GW- 273 recorded significantly higher plant height $(26.81 \mathrm{~cm})$, followed by Lok-1 $(26.39 \mathrm{~cm})$ at 30 DAS, variety LOk-1 recorded significantly higher plant height $(62.77 \mathrm{~cm} \mathrm{\&} 78.24 \mathrm{~cm})$ followed by Sujata $(56.01 \mathrm{~cm} \mathrm{\&} \mathrm{75.70)} \mathrm{at} \mathrm{(45} \mathrm{and} 60$ DAS) respectively. Significantly higher plant height recorded of variety Sujata at 75 DAS (113.04 $\mathrm{cm}), 90$ DAS $(113.51 \mathrm{~cm})$ and at harvest $(114.06 \mathrm{~cm})$ followed by Kanchan $88.50 \mathrm{~cm}$, $90.18 \mathrm{~cm}, 90.87 \mathrm{~cm}$ at 75 DAS, 90 DAS and at harvest respectively. In case of varieties 
difference in plant height may be due to their genetic characters.

\section{Number of tillers $\mathbf{m}^{-2}$}

The number of tillers $\mathrm{m}^{-2}$ increased with increasing the crop age up to 90 DAS, but the number of tillers at maturity slightly reduced. The number of tillers of wheat varieties influenced significantly, whereas number of tillers did not influenced due to residue management practices (Table 2). Among the residue management practices treatment residue retention recorded relatively higher number of tillers (427.92) at 15 DAS, while treatment residue incorporation recorded relatively higher number of tillers (693.75) at 30 DAS, (862.50) at $45 \mathrm{DAS},(618.75)$ at 60 DAS, (549.08) at 75 DAS, (545.67) at 90 DAS and (544.92) at harvest. Similarly in Dera Ismail Khan (Pakistan) Usman et al., (2014), recorded that rice straw incorporation by tillage resulted the higher number of tillers $\mathrm{m}^{-2}$.

Number of tillers of wheat varieties influenced significantly at all the stages of crop growth except 15 DAS. Among the varieties Sujata recorded significantly higher number of tillers (749.44), (901.11) and (652.22) followed by Lok-1 (685.56), (762.78) and (642.22) at $30 \mathrm{DAS}, 45$ DAS and 60 DAS respectively, whereas lowest number of tillers recorded with GW-273 at above DAS. Variety Lok-1 recorded significantly higher number of tillers (577.22), (577.00) and (576.44) followed by Kankchan (552.11), (550.56) and (549.78) at 75 DAS, 90 DAS and at harvest respectively, whereas lowest number of tillers recorded with GW-273 at above DAS.

\section{Days to occurrence of crop growth stages}

The days to occurrence of crop growth stages more influenced due to varieties and less influenced due to residue management practices. All the varieties start germination in 5 day. Variety Sujata taken more time for $1^{\text {st }}$ true leaf stage (8.67 day), 3 leaf stage (16.33 day), CRI (22.33 day), panicle emergence (67.33 day), 50\% flowering (71.33 day), milking (85 day) and maturity (113 day) followed by Kanchan for $1^{\text {st }}$ true leaf stage (8.33 day), 3 leaf stage (16.33 day), panicle emergence (60.67 day), 50\% flowering (65.67 day), milking (82 day) and maturity (105 day)

\section{Grain and straw yield and harvest index}

The grain and straw yield and harvest index significantly influenced due varieties, whereas grain and straw yield and harvest index did not influenced due to residue management practices (Table 3). Among the residue management practices treatment Residue incorporation recorded relatively higher grain yield (40.63 $\mathrm{q} \mathrm{ha}^{-1}$ ) and straw yield (32.92 q $\mathrm{ha}^{-1}$ ) followed by treatment Residue burnt along with tillage recorded grain yield (39.96 $\mathrm{q} \mathrm{ha}^{-1}$ ) and straw yield (29.81 $\left.\mathrm{q} \mathrm{ha}^{-1}\right)$, whereas treatment residue retention recorded relatively higher harvest index $(57.54 \%)$ followed by treatment residue burnt along with tillage (56.93\%). In Pantnagar, Dotaniya (2013) recorded that rice crop residue incorporation resulted the highest wheat yield (6.35 $\left.\mathrm{q} \mathrm{ha}^{-1}\right)$. Similarly in Dera Ismail Khan (Pakistan), Usman et al., (2014) recorded that rice straw incorporation by tillage resulted the highest wheat yield $\left(46.70 \mathrm{q} \mathrm{ha}^{-1}\right)$. Higher grain and straw yield of wheat with treatment Residue incorporation was mainly attributed with higher growth parameters like plant height and number of tillers.

Among the varieties Lok-1 produces significantly higher grain yield (43.36 q ha-1) followed by Kanchan (41.56 q ha ${ }^{-1}$ ), GW-273 (40.66 q ha ${ }^{-1}$ ), and Sujata (33.07 q ha-1). Variety Sujata produces significantly higher straw yield (34.83 q ha ${ }^{-1}$ followed by 
Kanchan (30.28 q ha $\left.{ }^{-1}\right)$, GW-273 (30.11 q $\left.\mathrm{ha}^{-1}\right)$ and Lok-1 (27.36 q ha $\left.{ }^{-1}\right)$. Harvest index significantly higher under variety Lok-1 $(61.35 \%)$ followed by Kanchan $(58.74 \%)$, GW-273(58.19\%) and Sujata (48.88\%).
Higher grain and straw yield of wheat variety Lok-1 was mainly attributed with higher number of tillers at reproductive stage and lower plant height (Table 4; Fig. 1 and 2).

Table.1 Plant height of wheat varieties as influenced by crop residue management practices

\begin{tabular}{|c|c|c|c|c|c|c|c|}
\hline \multirow[t]{2}{*}{ Treatment } & \multicolumn{7}{|c|}{ Plant height $(\mathrm{cm})$} \\
\hline & 15 DAS & 30 DAS & 45 DAS & 60 DAS & 75 DAS & 90 DAS & $\begin{array}{c}\text { At } \\
\text { harvest }\end{array}$ \\
\hline \multicolumn{8}{|c|}{ Crop residue management practices } \\
\hline $\begin{array}{l}\text { Residue Burnt + } \\
\text { tillage }\end{array}$ & 15.36 & 26.01 & 55.73 & 73.41 & 93.01 & 94.02 & 94.81 \\
\hline Residue incorporation & 16.44 & 26.42 & 57.51 & 75.09 & 93.28 & 96.74 & 97.28 \\
\hline Residue retention & 16.90 & 25.43 & 57.35 & 73.61 & 91.93 & 93.49 & 93.95 \\
\hline SEm \pm & 1.34 & 1.56 & 3.29 & 1.50 & 2.72 & 1.48 & 1.40 \\
\hline $\mathrm{CD}(\overline{\mathbf{P}}=\mathbf{0 . 0 5})$ & NS & NS & NS & NS & NS & NS & NS \\
\hline \multicolumn{8}{|l|}{ Varieties } \\
\hline GW-273 & 17.66 & 26.81 & 53.53 & 69.92 & 86.68 & 89.58 & 90.03 \\
\hline Lok-1 & 15.50 & 26.39 & 62.77 & 78.24 & 82.75 & 85.72 & 86.41 \\
\hline Kanchan & 15.49 & 26.38 & 55.14 & 72.28 & 88.50 & 90.18 & 90.87 \\
\hline Sujata & 16.28 & 24.24 & 56.01 & 75.70 & 113.04 & 113.51 & 114.06 \\
\hline SEm \pm & 0.51 & 0.61 & 1.10 & 1.25 & 1.74 & 1.57 & 1.64 \\
\hline $\mathrm{CD}(\overline{\mathrm{P}}=\mathbf{0 . 0 5})$ & 1.52 & 1.80 & 3.27 & 3.72 & 5.16 & 4.66 & 4.87 \\
\hline
\end{tabular}

DAS- Days after sowing

Table. 2 Number tillers of wheat varieties as influenced by crop residue management practices

\begin{tabular}{|c|c|c|c|c|c|c|c|}
\hline \multirow[t]{2}{*}{ Treatment } & \multicolumn{7}{|c|}{ Number of tillers $\left(\mathrm{m}^{-2}\right)$} \\
\hline & 15 DAS & 30 DAS & 45 DAS & 60 DAS & 75 DAS & 90 DAS & $\begin{array}{c}\text { At } \\
\text { harvest }\end{array}$ \\
\hline \multicolumn{8}{|c|}{ Crop residue management practices } \\
\hline $\begin{array}{l}\text { Residue Burnt + } \\
\text { tillage }\end{array}$ & 397.92 & 652.08 & 816.67 & 597.08 & 532.08 & 521.25 & 520.83 \\
\hline Residue incorporation & 396.25 & 693.75 & 862.50 & 618.75 & 549.08 & 545.67 & 544.92 \\
\hline Residue retention & 427.92 & 677.50 & 645.83 & 576.67 & 509.58 & 516.17 & 514.33 \\
\hline SEm \pm & 25.82 & 65.31 & 43.78 & 53.01 & 23.73 & 24.57 & 24.45 \\
\hline $\mathrm{CD}(\overline{\mathbf{P}}=\mathbf{0 . 0 5})$ & NS & NS & NS & NS & NS & NS & NS \\
\hline \multicolumn{8}{|l|}{ Varieties } \\
\hline GW-273 & 413.33 & 597.78 & 701.11 & 515.00 & 480.00 & 476.67 & 475.89 \\
\hline Lok-1 & 378.89 & 685.56 & 762.78 & 642.22 & 577.22 & 577.00 & 576.44 \\
\hline Kanchan & 417.78 & 665.00 & 735.00 & 607.22 & 552.11 & 550.56 & 549.78 \\
\hline Sujata & 419.44 & 749.44 & 901.11 & 652.22 & 511.67 & 506.56 & 504.67 \\
\hline SEm \pm & 18.40 & 27.63 & 20.06 & 28.63 & 22.47 & 24.56 & 25.29 \\
\hline $\mathrm{CD}(\mathrm{P}=0.05)$ & NS & 82.10 & 59.59 & 85.06 & 66.77 & 72.97 & 75.14 \\
\hline
\end{tabular}


Table.3 Occurrence of crop stages of wheat varieties as influenced by crop residue management practices

\begin{tabular}{|c|c|c|c|c|c|c|c|c|}
\hline \multirow[t]{2}{*}{ Treatment } & \multicolumn{8}{|c|}{ Occurrence of crop stage (Day) } \\
\hline & $\begin{array}{l}\text { Germi } \\
\text { nation }\end{array}$ & $\begin{array}{c}1^{\text {st }} \text { true } \\
\text { leaf }\end{array}$ & 3 leaf & CRI & $\begin{array}{c}\text { Panicle } \\
\text { emergence }\end{array}$ & $\begin{array}{l}50 \% \\
\text { Flowering }\end{array}$ & Milking & Maturity \\
\hline \multicolumn{9}{|c|}{ Crop residue management practices } \\
\hline Residue Burnt + tillage & 5.0 & 8.0 & 16.50 & 21.25 & 60.50 & 65.00 & 80.50 & 107.0 \\
\hline Residue incorporation & 5.0 & 8.25 & 15.75 & 21.25 & 62.00 & 65.75 & 81.00 & 107.0 \\
\hline Residue retention & 5.0 & 8.50 & 16.0 & 21.50 & 60.50 & 64.25 & 80.50 & 107.0 \\
\hline \multicolumn{9}{|l|}{ Varieties } \\
\hline GW-273 & 5.0 & 8.0 & 15.67 & 22.33 & 58.67 & 62.00 & 78.33 & 105.0 \\
\hline Lok-1 & 5.0 & 8.0 & 16.0 & 20.0 & 57.33 & 61.00 & 77.33 & 104.0 \\
\hline Kanchan & 5.0 & 8.33 & 16.33 & 21.0 & 60.67 & 65.67 & 82.00 & 105.0 \\
\hline Sujata & 5.0 & 8.67 & 16.33 & 22.0 & 67.33 & 71.33 & 85.00 & 113.0 \\
\hline
\end{tabular}

Table.4 Yield parameters of wheat varieties as influenced by crop residue management practices

\begin{tabular}{|c|c|c|c|}
\hline Treatment & Grain yield $\left(q\right.$ ha $\left.^{-1}\right)$ & Straw yield $\left(q\right.$ ha $\left.^{-1}\right)$ & Harvest index $(\%)$ \\
\hline \multicolumn{4}{|c|}{ Crop residue management practices } \\
\hline Residue Burnt + tillage & 39.96 & 29.81 & 56.93 \\
\hline Residue incorporation & 40.63 & 32.92 & 55.90 \\
\hline Residue retention & 38.40 & 29.16 & 57.54 \\
\hline $\mathrm{SEm} \pm$ & 2.40 & 1.45 & 1.93 \\
\hline $\mathrm{CD}(\overline{\mathbf{P}}=\mathbf{0 . 0 5})$ & NS & NS & NS \\
\hline \multicolumn{4}{|l|}{ Varieties } \\
\hline GW-273 & 40.66 & 30.11 & 58.19 \\
\hline Lok-1 & 43.36 & 27.36 & 61.35 \\
\hline Kanchan & 41.56 & 30.28 & 58.74 \\
\hline Sujata & 33.07 & 34.83 & 48.88 \\
\hline SEm \pm & 2.34 & 2.27 & 2.13 \\
\hline $\mathrm{CD}(\overline{\mathrm{P}}=0.05)$ & 6.96 & 6.76 & 6.32 \\
\hline
\end{tabular}

Table.5 Economics of wheat production as influenced by crop residue management practices

\begin{tabular}{|c|c|c|c|c|}
\hline Treatment & $\begin{array}{c}\text { Cost of cultivation } \\
\left(\text { Rs. ha }{ }^{-1}\right)\end{array}$ & $\begin{array}{l}\text { Gross return } \\
\quad\left(\text { Rs. ha } \text { h }^{-1}\right)\end{array}$ & $\begin{array}{l}\text { Net return } \\
\left(\text { Rs. ha }{ }^{-1}\right)\end{array}$ & B: C ratio \\
\hline \multicolumn{5}{|c|}{ Crop residue management practices } \\
\hline Residue Burnt + tillage & 26505.00 & 63345.00 & 36840.00 & 2.39 \\
\hline Residue incorporation & 26265.00 & 64541.00 & 38276.00 & 2.46 \\
\hline Residue retention & 21715.00 & 61023.00 & 39308.00 & 2.81 \\
\hline \multicolumn{5}{|l|}{ Varieties } \\
\hline GW-273 & 24678.00 & 62012.00 & 37334.00 & 2.51 \\
\hline Lok-1 & 24678.00 & 66130.00 & 41452.00 & 2.68 \\
\hline Kanchan & 24678.00 & 63386.00 & 38708.00 & 2.57 \\
\hline Sujata & 25278.00 & 60349.00 & 35071.00 & 2.39 \\
\hline
\end{tabular}

Seed price: Rs. $2600 \& 3200 \mathrm{q}^{-1}$ (Sujata), Grain sale price: Rs. $1525 \& 1825 \mathrm{q}^{-1}$ (Sujata) 
Fig.1 Occurrence of crop growth stages of wheat varieties as influenced by crop residue management practices

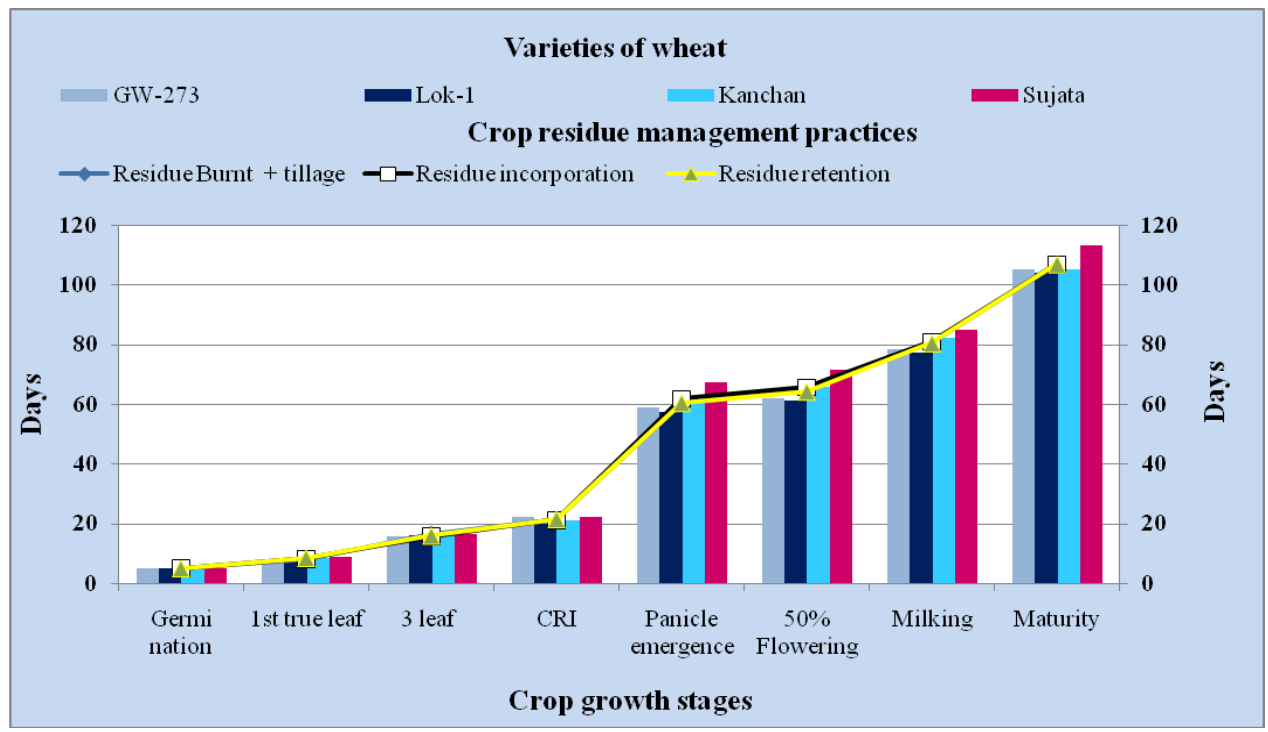

Fig.2 Weekly meteorological data prevailing during crop growth period (Rabi, 2016-17)

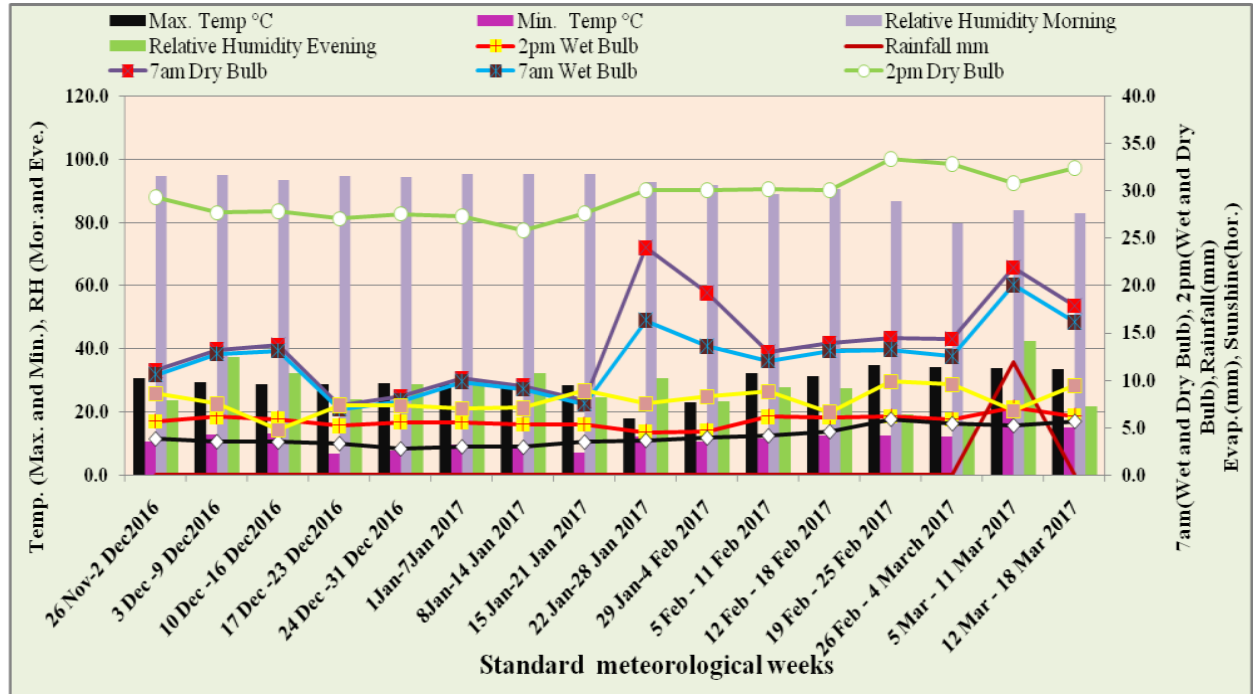

\section{Economics of wheat production}

Effect of different treatments cannot be assessed without the gross and net return from that treatment. The economics of different treatments have been presented in Table 5. Among the crop residue management practices treatment residue incorporation recorded the highest gross return (Rs. ha ${ }^{-1}$ 64,541) followed by residue burnt along with tillage (Rs. ha ${ }^{-1}$ 63,345), whereas treatment residue retention recorded highest net return. (Rs. ha ${ }^{-1}$ 39,308) and B: C ratio (Rs. 2.81) followed by residue incorporation net return. (Rs. ha ${ }^{-1}$ 38,276) and B: C ratio (Rs. 2.46). Higher net return and $\mathrm{B}$ : $\mathrm{C}$ ratio was due lowest cost of cultivation. Among the varieties, Lok-1 recorded highest gross return (Rs. ha ${ }^{-1}$ 66,130), net return (Rs. ha ${ }^{-1} 41,452$ ) and B: C ratio (Rs. 2.68) followed by 
Kanchan with gross return (Rs. ha ${ }^{-1}$ 63,386), net return (Rs. ha ${ }^{-1}$ 38,708) and B: C ratio (Rs. 2.57). In Varanasi, Rakesh et al., (2019) recorded that rice crop residue retention practices resulted higher net return of wheat (Rs. ha ${ }^{-1}$ 20,619) in 2006 and (Rs. ha ${ }^{-1}$ 30, 854) in 2007.

On the basis of experimental findings, it is concluded that wheat should be sown under crop residue incorporation for obtaining higher grain and straw yield and gross return, whereas wheat should be sown under crop residue retention for obtaining higher net return under rice-wheat cropping system. Wheat varieties Lok- 1 and Kanchan should be sown for obtaining higher grain yield, gross and net return in the region.

\section{References}

Anonymous. 2018. Directorate of Agriculture. Government of Chhattisgarh, Raipur.

Farooq U., Sharif M. and Erenstein O. 2007. Adoption and impacts of zero tillage in the rice-wheat zone of irrigated Punjab, Pakistan. Research report. New Delhi: CIMMYT \& RWC.

Gangwar K. S., Singh K. K., Sharma S. K. and Tomar O. K. 2006 Alternative tillage and crop residue management in wheat after rice in sandy loam of Indo-Gangetic plains. Soil and Tillage Research, 88: 242-252.
K. Kumar and K.M. Goh. 1999. Crop residue and management practices: Effects on soil quality, soil nitrogen dynamics, crop yield and nitrogen recovery. Advances in Agronomy 68: 197-319.

Khalid Usman, Ejaz Ahmad Khan, Niamatullah Khan, Abdur Rashid, Fazal Yazdan and Saleem ud Din. 2014. Response of wheat to tillage plus rice residue and nitrogen management in rice-wheat system. Journal of Integrative Agriculture Doi: 10.1016/S2095-3119(13)607285.

M. L. Dotaniya. 2013. Impact of crop residue management practices on yield and nutrient uptake in rice-wheat system. Current Advances in agricultural Sciences 5(2): 269-271.

Rakesh Kumar, U.P. Singh and Gaurav Mahajan. 2019. Performance of Zerotill Wheat (Triticum aestivum L.) and Weed Species as Influenced by Residue and Weed Management Techniques in Rice based Cropping System. Int.J.Curr.Microbiol.App.Sci. 8(04): 270-277.

Saharawat Yashpal, Singh Bhagat, Malik, R.K., and Ladha, J.K. 2010. Evaluation of alternative tillage and crop establishment methods in a ricewheat rotation in North Western IGP. Field Crop Research 116: 260-267.

\section{How to cite this article:}

Anil Kumar Netam, Birbal Sahu, Chainu Ram Netam and Suresh Kumar Markam. 2019. Performance of Crop Residue Management Practices on Growth and Yield of Wheat (Triticum aestivum L.) under Rice- wheat System in Bastar Region of Chhattisgarh, India. Int.J.Curr.Microbiol.App.Sci. 8(06): 150-157. doi: https://doi.org/10.20546/ijcmas.2019.806.019 